\title{
Limbah Cair Industri Tahu dan Dampaknya Terhadap Kualitas Air dan Biota Perairan
}

\author{
Henny Pagoray ${ }^{1 *}$, Sulistyawati $^{2}$, dan Fitriyani ${ }^{3}$ \\ ${ }^{1,2}$ Staf Pengajar Program Studi Akuakultur, Jurusan Budidaya Perairan, \\ Fakultas Perikanan dan IImu Kelautan, Universitas Mulawarman \\ ${ }^{3}$ Mahasiswa Program Studi Akuakultur, Jurusan Budidaya Perairan, \\ Fakultas Perikanan dan IImu Kelautan, Universitas Mulawarman \\ 1 Email: pagoray.henny@gmail.com \\ *Penulis korespondensi: pagoray.henny@gmail.com
}

\begin{abstract}
Tofu industrial liquid waste will affect water bodies if it was directly disposed of without prior management and causes water quality and aquatic life problems. This study aims to examine the impact of the tofu industrial wastewater concentration on water quality, swimming patterns, and fish behavior. The research was conducted by testing in the laboratory using an aquarium and analyzed descriptively. The treatments that were tried were liquid waste tofu with a concentration of $0 \% ; 0.4 \%$; $0.6 \% ; 0.8 \% ; 1.0 \%$ and $1.2 \%$ of the volume of 10 liters of water. Each aquarium was filled with 24 fish with a size of $4-5 \mathrm{~cm}$. The observation method was carried out for 96 hours. The results of water quality measurements of $\mathrm{pH}, \mathrm{DO}, \mathrm{CO}_{2}, \mathrm{COD}, \mathrm{TSS}$, and $\mathrm{H}_{2} \mathrm{~S}$ exceed the quality standard, while the temperature, $B O D_{5}$, and ammonia are still below the quality standard. Fish behavior moves to avoid waste, swarming behavior while fish swimming patterns swim on the surface, swim irregularly, swimming patterns change with a standing position. The concentration of tofu wastewater was $0.4 \% ; 0.6 \% ; 8 \% ; 1.0 \%$ and $1.2 \%$ affect swimming patterns and fish behavior.
\end{abstract}

Keywords: Fish Behavior, Liquid Waste, Swimming Patterns, Tofu Industry, Water Quality

\begin{abstract}
ABSTRAK
Limbah cair industri tahu akan berpengaruh terhadap badan air apabila langsung dibuang tanpa dilakukan pengelolaan terlebih dahulu, dan menyebabkan masalah terhadap kualitas air dan kehidupan biota akuatik. Penelitian ini bertujuan untuk menguji dampak konsentrasi limbah cair industri tahu terhadap kualitas air, pola renang dan tingkah laku ikan. Penelitian dilakukan dengan uji coba di Laboratorium menggunakan akuarium dan dianalisis secara deskriptif. Adapun perlakuan yang dicobakan adalah limbah cair tahu dengan konsentrasi $0 \% ; 0,4 \% ; 0,6 \% ; 0,8 \% ; 1,0 \%$ dan $1,2 \%$ dari volume air 10 liter. Setiap akuarium diisi ikan sebanyak 24 ekor dengan ukuran 4-5 cm. Metode Pengamatan dilakukan selama 96 jam. Hasil pengukuran kualitas air $\mathrm{pH}, \mathrm{DO}, \mathrm{CO}_{2}, \mathrm{COD}$, TSS dan $\mathrm{H}_{2} \mathrm{~S}$ melebihi standar baku mutu, sedangkan suhu, $\mathrm{BOD}_{5}$ dan amoniak masih dibawah standar baku mutu. Tingkah laku ikan bergerak menghindari limbah, perilaku bergerombol sedangkan pola renang ikan berenang dipermukaan, berenang tidak beraturan, pola renang berubah dengan posisi berdiri. Konsentrasi limbah cair tahu $0,4 \% ; 0,6 \% ; 8 \% ; 1,0 \%$ dan $1,2 \%$ berpengaruh terhadap pola renang dan tingkah laku ikan.
\end{abstract}

Kata kunci: Industri Tahu, Kualitas Air, Limbah Cair, Pola Renang, Tingkah Laku Ikan 


\section{Pendahuluan}

Tahu adalah jenis makanan yang memiliki nilai gizi, mengandung protein dengan bahan dasar kacang kedelai. Kebutuhan terhadap kedelai mencapai 2,3 juta ton pertahun, dimana $40 \%$ yang dikonsumsi berupa tahu, 50\% berupa tempe dan 10\% minyak kedelai (Buchori et al., 2012). Industri tahu dapat meningkatkan perekonomian masyarakat, tetapi juga dapat memberi dampak negatif karena limbah yang dihasilkan dapat mencemari lingkungan (Matilda et al., 2016).

Pengolahan tahu akan menghasilkan buangan atau ada sisa yang dapat berupa limbah. Limbah apabila tidak dilakukan penanganan dengan baik akan menyebabkan pencemaran (Indah et al., 2014). Limbah tahu merupakan sisa pengolahan kedelai yang terbuang karena tidak terbentuk menjadi tahu. Limbah tahu ada dalam bentuk padat dan cair. Limbah bentuk padat yang merupakan kotoran hasil pembersihan kedelai, sisa bubur biasa disebut ampas tahu, sedangkan hasil pencucian tahu, berupa limbah cair. Limbah yang dominan terbuang yaitu dalam bentuk cair dan berpotensi mencemari perairan. Pada proses produksi tahu akan menghasilkan limbah cair yang berasal dari pembersihan kedelai, pembersihan peralatan, perendaman, pencetakan dan apabila dibuang langsung ke perairan akan berbau busuk dan mencemari lingkungan (Kaswinarni, 2008). Menurut Rolia \& Amran (2015), limbah tahu yang tidak diolah berbau dan berwarna hitam.

Industri tahu yang menghasilkan limbah cair, apabila tidak dilakukan pengelolaan dan di dibuang ke perairan, akan mempengaruhi sifat fisik, kimia air yang berpengaruh pada kelangsungan hidup organisme perairan. Para pelaku usaha tidak menyadari dan minimnya wawasan tentang pengelolaan limbah cair tahu yang akan berdampak ke lingkungan (Nasir et al., 2015). Air limbah tahu harus dilakukan pengolahan sebelum limbah tersebut dibuang ke perairan untuk mencegah timbulnya masalah buangan limbah tahu (Suganda et al., 2014). Limbah Industri tahu memiliki kandungan bahan C-organik, yang mempengaruhi kadar BOD dan COD. Menurut Herlambang (2005) buangan dari tahu yang mengandung bahan organik dan gas seperti oksigen terlarut $\left(\mathrm{O}_{2}\right)$, hydrogen sulfida $\left(\mathrm{H}_{2} \mathrm{~S}\right)$, Karbondioksida $\left(\mathrm{CO}_{2}\right)$, dan amoniak $\left(\mathrm{NH}_{3}\right)$. Gas-gas ini apabila melebihi standar, maka akan berpengaruh terhadap kehidupan biota perairan. Menurut Agung \& Winata (2011), limbah tahu yang mengandung BOD, COD dan bahan organik tinggi akan berpengaruh terhadap daya dukung lingkungan.

Kelangsungan hidup biota yang ada dalam perairan akan sangat dipengaruhi oleh kualitas air. Kualitas air akan berubah apabila ada bahan yang masuk, seperti bahan organik yang dapat mencemari perairan, menghasilkan produk dekomposisi berupa ammonia $\left(\mathrm{NH}_{3}\right), \mathrm{CO}_{2}, \mathrm{H}_{2} \mathrm{~S}, \&$ asam asetat yang dapat bersifat racun bagi biota perairan, dan menurunnya kualitas perairan yang menyebabkan gangguan terhadap kehidupan biota akuatik. Apabila limbah ini dialirkan ke sungai terus menerus, berdampak buruk pada 
ISSN 2354-7251 (print)

lingkungan perairan termasuk bagi ikan-ikan budidaya yang dipelihara pada keramba di lingkungan perairan tersebut, \& ekosistem lingkungan perairan menjadi tidak stabil.

Hasil penelitian Rohmani (2014), buangan dari kegiatan industri tahu apabila tidak dilakukan pengolahan terlebih dahulu dapat mengganggu kehidupan biota perairan. Berdasarkan urairan tersebut, maka dilakukan penelitian uji coba di laboratorium untuk melihat pengaruh limbah cair industri tahu terdapa kualitas air dan kelayakan untuk kehidupan biota perairan. Tujuan dari penelitian yaitu untuk menguji dampak konsentrasi limbah cair industr tahu terhadap kualitas air dan kelayakan kehidupan biota perairan dengan melihat tingkah laku ikan dan pola renang.

\section{Metode Penelitian}

\section{Waktu dan Tempat}

Pelaksanaan penelitian dilakukan mulai bulan Februari hingga Juli 2020, di Laboratorium Toksikologi Perairan, Jurusan Budidaya Perairan, Fakultas Perikanan dan IImu Kelautan, Universitas Mulawarman. Sampel limbah cair tahu diambil di lokasi pembuatan tahu sekitar sungai Karang Mumus Samarinda Kalimantan Timur.

\section{Alat dan Bahan}

Alat yaitu akuarium berukuran $25 \mathrm{~cm}$ x $25 \mathrm{~cm} \times 25 \mathrm{~cm}$ sebanyak 6 akuarium untuk media perlakuan, bak untuk menampung ikan, gentong untuk menampung air yang akan diendapkan, serok dan ember, peralatan aerator, water cheker untuk mengukur kualitas air, dan peralatan laboratorium seperti gelas ukur, erlenmayer, kalkulator, alat tulis, serta kamera. Bahan yaitu benih ikan mas (Cyprinus carpio $L$ ) ukuran $4-5 \mathrm{~cm}$ dengan bobot ratarata 1-1,5 gram, limbah cair tahu, pakan ikan (selama aklimasi), dan kertas label, bahan kimia untuk analisis kualitas air.

\section{Prosedur Penelitian}

Proses percobaan (penelitian) dengan menggunakan media uji (akuarium) diisi air sebanyak 10 liter. Setiap akuarium diisi ikan sebanyak 24 ekor dengan ukuran rata-rata 4$5 \mathrm{~cm}$, berat 1-1,5 grm. Perlakuan yang akan digunakan adalah cairan limbah tahu dengan konsentrasi yang berbeda. Penentuan konsentrasi berdasarkan rumus dari Komisi Pestisida (Departemen Pertanian, 1983). Perlakuan penelitian yaitu :

1. Konsentrasi limbah cair tahu $0 \%$

2. Konsentrasi limbah cair tahu $0,4 \%$

3. Konsentrasi limbah cair tahu 0,6\%

4. Konsentrasi limbar cair tahu 0,8\%

5. Konsentrasi limbah cair tahu $1 \%$

6. Konsentrasi limbah cair tahu $1,2 \%$ 
Pengukuran kualitas air seperti Temperatur (suhu), keasaman (pH), oksigen terlarut $\left(\mathrm{O}_{2}\right)$, karbondioksida $\left(\mathrm{CO}_{2}\right), \mathrm{BOD}, \mathrm{COD}, \mathrm{TSS}, \mathrm{H}_{2} \mathrm{~S}, \mathrm{NH}_{3}$, Untuk parameter Suhu, $\mathrm{pH}, \mathrm{DO}$ setiap 24 jam sekali, parameter $\mathrm{CO}_{2}$ setiap 48 jam dan 96 jam, dan parameter $\mathrm{BOD}, \mathrm{COD}$, TSS, $\mathrm{NH}_{3}$, pada awal dan akhir pemasukan bahan limbah cair tahu. Pada penelitian ini juga dilakukan pengamatan terhadap tingkah laku ikan (ikan bergerak-gerak menghindari limbah, perilaku bergerombol) dan pola renang dari ikan (ikan berenang dipermukaan, berenang tidak beraturan, pola renang berubah dengan posisi berdiri).

\section{Metode Analisis Data}

Hasil pengamatan terhadap pola renang dan tingkah laku ikan dibuat dalam bentuk Tabel. Kualitas air yang di analisis yaitu kualitas air pada jam yang ke 96 (96 jam), dan hasilnya dibandingkan dengan baku mutu limbah cair tahu. Baku mutu limbah cair tahu menurut Peraturan Daerah Kaltim No. 2 Tahun 2011, (Lampiran I. I.30) dan baku mutu Lampiran V Kelas II. Dapat dilihat pada Tabel 1, dan juga dibandingkan dengan standar kualitas air yang layak untuk kehidupan biota.

Tabel 1. Baku mutu parameter uji air limbah tahu dan kualitas air sungai

\begin{tabular}{clccc}
\hline No. & Parameter & Kadar & Baku mutu* $^{*}$ & Baku mutu $^{* *}$ \\
\hline 1. & $\mathrm{T}($ suhu $)$ & ${ }^{\circ} \mathrm{C}$ & $38^{\circ} \mathrm{C}$ & Devias 13 \\
2. & $\mathrm{pH}$ & - & $6-9$ & $6-9$ \\
3. & $\mathrm{DO}$ & $\mathrm{mg} / \mathrm{l}$ & - & 4 \\
4. & Ammonia & $\mathrm{mg} / \mathrm{l}$ & 1 & $(-)$ \\
5. & $\mathrm{TSS}$ & $\mathrm{mg} / \mathrm{l}$ & 100 & 50 \\
6. & $\mathrm{BOD} 5$ & $\mathrm{mg} / \mathrm{l}$ & 150 & 3 \\
7. & $\mathrm{COD}$ & $\mathrm{mg} / \mathrm{l}$ & 300 & 25 \\
8. & $\mathrm{H}_{2} \mathrm{~S}$ & $\mathrm{mg} / \mathrm{l}$ & 0,05 & 0,002 \\
\hline
\end{tabular}

Keterangan: Baku mutu limbah cair tahu menurut Peraturan daerah Kaltim No. 2 Tahun 2011 tentang pengelolaan kualitas air dan pengendalian kualitas air (Lamp. I. 1.30), (**) Lamp. V, kelas II

\section{Hasil dan Pembahasan}

\section{Suhu}

Hasil pengamatan pengukuran suhu air pada percobaan yang dilakukan di laboratorium dengan adanya perbedaan jumlah limbah pada pengamatan 96 jam yaitu berada pada kisaran $25-27^{\circ} \mathrm{C}$. Hasil pengukuran suhu dapat dilihat pada Gambar 1. Pada Gambar terlihat bahwa suhu air pada konsentrasi limbah $0,6 \%$ tertinggi yaitu $27^{\circ} \mathrm{C}$, dan terendah $25^{\circ} \mathrm{C}$ pada perlakuan $0 \%$ limbah tahu. Hasil pengukuran suhu jika dibandingan dengan baku mutu Perda Provinsi Kalimantan Timur tentang pengelolaan kualitas air dan pengendalian pencemar air Nomor 02 Tahun 2011, Lampiran I.30, Baku mutu air limbah untuk kegiatan industri tahu, masih berada pada kondisi yang sesuai dengan standar. Suhu perairan berpengaruh terhadap kelangsungan hidup ikan, mulai dari telur, larva dan benih sampai ukuran dewasa, selain itu juga berpengaruh terhadap laju metabolisme hewan akuatik. Faktor-faktor yang berpengaruh terhadap suhu perairan yaitu adanya sinar matahari, pertukaran panas antara air dan udara di sekitarnya. Suhu perairan juga 
dipengaruhi oleh adanya buangan berupa limbah yang menyebkan suhu air menjadi berubah.

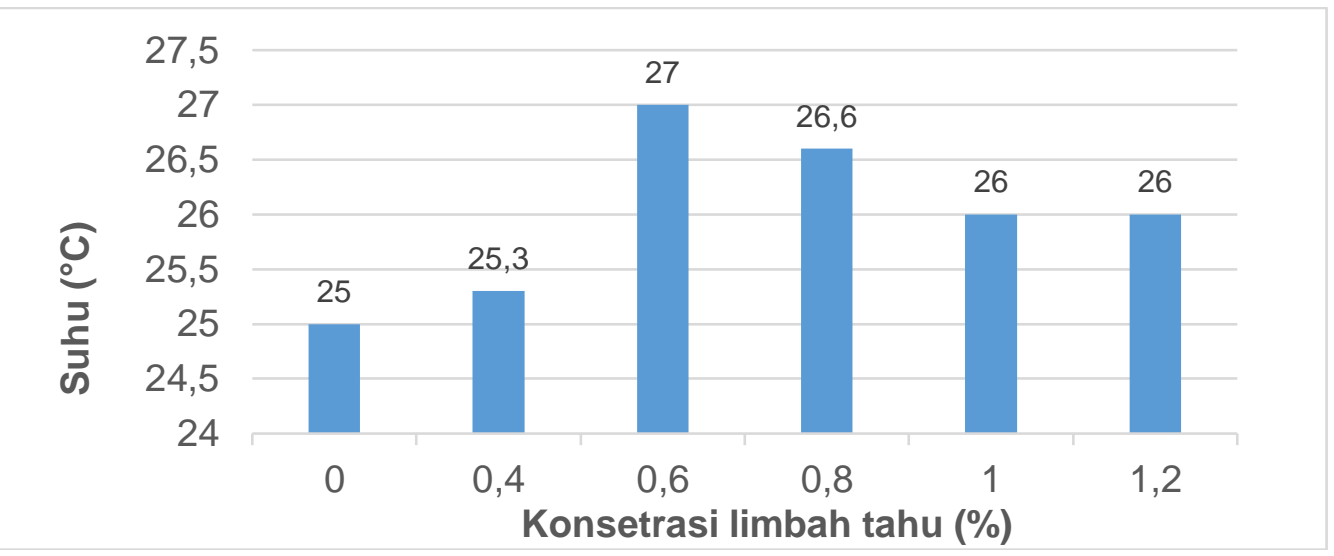

Gambar 1. Hasil pengukuran suhu air dengan konsentrasi limbah tahu yang berbeda

\section{Derajat Keasaman (pH)}

Derajat keasaman $(\mathrm{pH})$ atau merupakan ion hydrogen dalam perairan. $\mathrm{pH}$ dalam perairan berpengaruh terhadap organisme perairan. Hasil pengukuran $\mathrm{pH}$ pada percobaan yang dilakukan di laboratorium dengan konsentrasi yang berbeda setelah 96 jam, berada pada kisaran $\mathrm{pH} 4,5-6,3$. Hasil pengamatan dapat dilihat pada Gambar 2. Pengukuran $\mathrm{pH}$ terendah pada konsentrasi limbah cair tahu 1,2\% dan tertinggi pada konsentrasi limbah cair tahu 0\%. Hasil ini jika dibandingkan dengan baku mutu Perda Provinisi Kalimantan Timur tentang pengelolaan kualitas air dan pengendalian pencemar air Nomor 02 Tahun 2011, Lampiran I.30, Baku mutu air limbah untuk kegiatan industri tahu,melebihi standar baku mutu yaitu pH 6 -9. Semakin tinggi limbah tahu juga berpengaruh terhadap $\mathrm{pH}$ air. $\mathrm{pH}$ industri tempe dan tahu yang masuk ke perairan berkisar 3,62-5,56 (Mardhia \& Abdullah, 2018). Hamzani \& Syarifudin (2020), menyatakan bahwa pH air limbah tahu berada pada kisaran 4,3-5,33. Air limbah tahu apabila masuk ke badan air berpotensi menurunkan $\mathrm{pH}$ air, dan berpengaruh terhadap biota perairan (organisme perairan) (Mardhia \& Abdullah, 2018). 


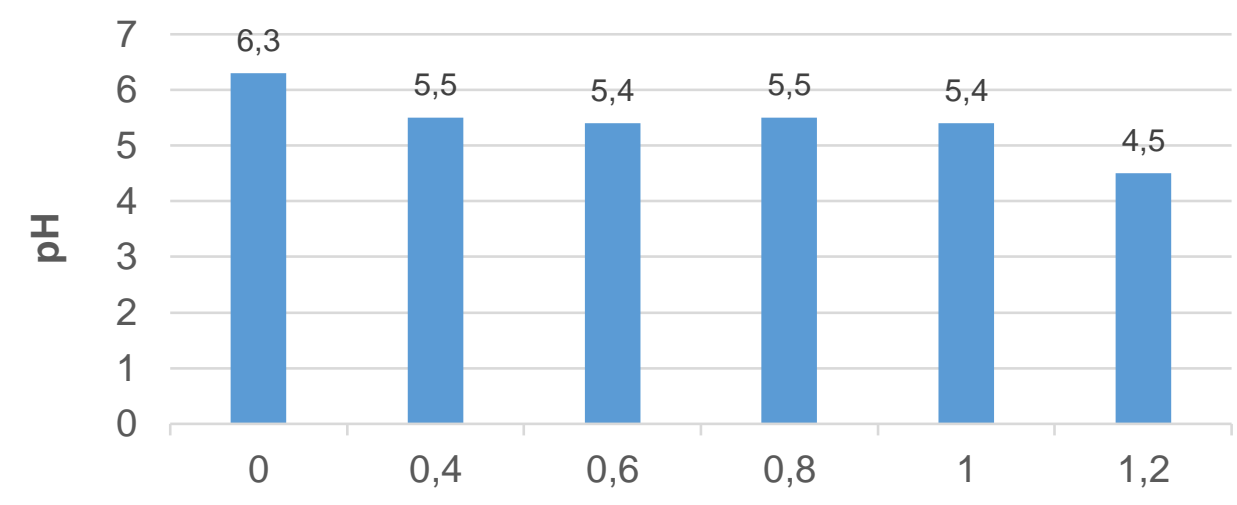

Konsetrasi limbah tahu (\%)

Gambar 2. Hasil pengukuran $\mathrm{pH}$ air dengan konsentrasi limbah tahu yang berbeda

\section{Dissolved oxygen (DO)}

Dissolved oxygen (DO) atau biasa disebut $\mathrm{O}_{2}$ (oksigen terlarut). Disolved oxygen dibutuhkan oleh jasad hidup untuk pernafasan dan metabolisme. Hasil pengukuran DO pada percobaan yang dilakukan setelah 96 jam, nilai DO berada pada kisaran 1,1-2 mg/l. Hasil pengamatan pengukuran DO terlihat pada Gambar 3. Nilai DO dari hasil ini jika dibandingkan dengan baku mutu Perda Provinisi Kalimantan Timur, tentang Pengelolaan Kualitas Air dan Pengendalian Pencemar Nomor 02 Tahun 2011, Lampiran I.30 , BM air limbah kegiatan industry tahu, standar baku mutu yaitu DO (-), tetapi apabila masuk ke perairan $4 \mathrm{mg} / \mathrm{l}$. Pada penelitian yang dilakukan terjadi penurunan oksigen terlarut karena proses respirasi organisme dan penguraian atau dekomposisi bahan organik yang terdapat dalam limbah tahu.

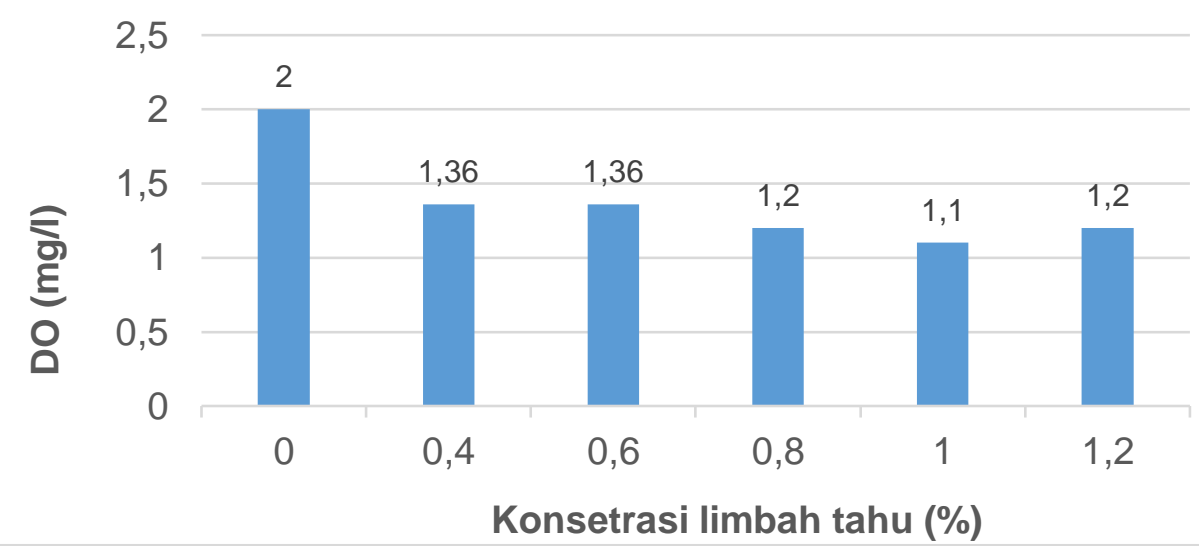

Gambar 3. Hasil pengukuran DO (mg/l) air dengan konsentrasi limbah tahu yang berbeda

\section{Karbondioksida $\left(\mathrm{CO}_{2}\right)$}

Karbondioksida $\left(\mathrm{CO}_{2}\right)$ mempunyai peranan yang besar bagi kehidupan organisme perairan. Hasil pengukuran $\mathrm{CO}_{2}$ pada percobaan yang dilakukan pada 96 jam nilai $\mathrm{CO}_{2}$ yaitu $8,26-10,5 \mathrm{mg} / \mathrm{l}$. Hasil pengukuran pada Gambar 4. Pengukuran pada gambar terlihat bahwa nilai $\mathrm{CO}_{2}$ tertinggi yaitu pada perlakuan 1,2\% limbah cair tahu, dengan nilai $\mathrm{CO}_{2}$ yaitu 10,5 mg/l. Jika dibandingkan dengan baku mutu Perda Provinisi Kalimantan Timur, 
ISSN 2354-7251 (print)

tentang pengendalian pencemar air dan pengelolaan kualitas air No. 02 tahun 2011, Lampiran V, kelas II yaitu $10 \mathrm{mg} / \mathrm{l}$, melebihi standar baku mutu. Pada perlakuan 1,2\%, nilai $\mathrm{CO}_{2}$ tertinggi ini disebabkan karena oksigen terlarut rendah. Peningkatan $\mathrm{CO}_{2}$ dalam perairan dapat mempengaruhi proses metabolisme yaitu masuk kedalam darah ikan melalui insang dan oksigen berkurang dan dapat menyebabkan ikan mengalami perdarahan.

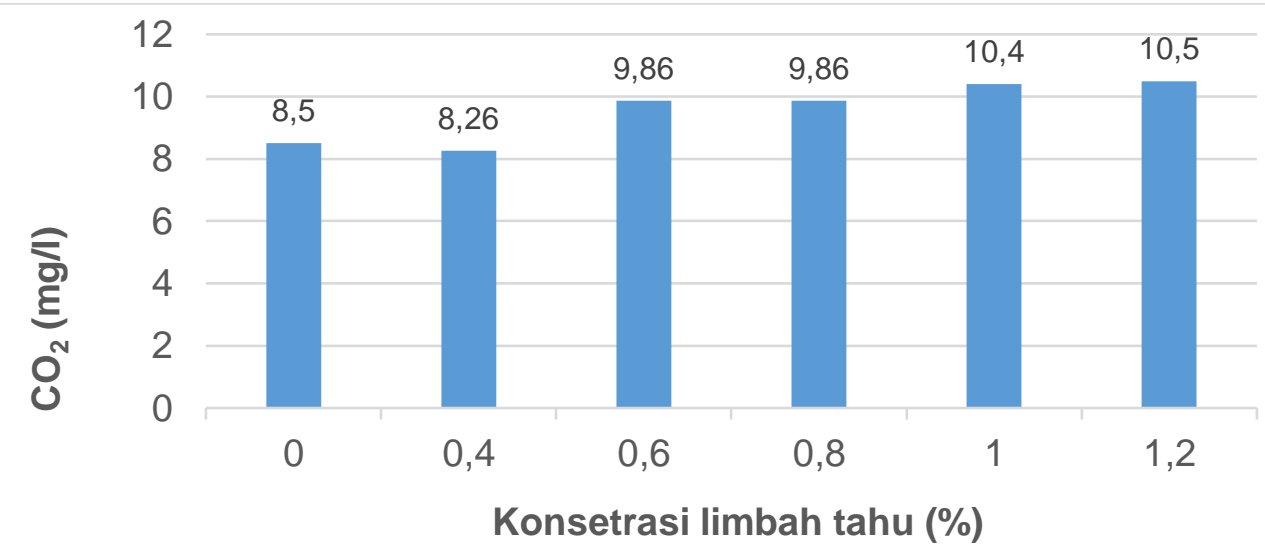

Gambar 4. Hasil pengukuran $\mathrm{CO}_{2}(\mathrm{mg} / \mathrm{l})$ air dengan konsentrasi limbah tahu yang berbeda Biological Oxygen Demand $\left(\mathrm{BOD}_{5}\right)$

Kebutuhan $\mathrm{O}_{2}$ (oksigen terlarut) untuk mikroorganisme yang digunakan untuk mengurai atau dekomposisi bahan-bahan organik biasa disebut BOD (Biological Oxygen Demand). Apabila nilai BOD menurun, maka bahan organik akan mengalami proses penguraian yang dilakukan oleh mikroorgnisme (Zulkifili \& Ami, 2001). Hasil pengukuran BOD limbah tahu pada percobaan yang dilakukan yaitu 5,96-121 mg/l. Hasil pengamatan kandungan BOD pada Gambar 5. Hasil ini masih dibawah standar jika dibandingkan dengan baku mutu Perda Provinisi Kalimantan Timur, mengenai pengelolaan kualitas air dan pengendalian pencemar air Nomor 02 Thn. 2011, Lampiran I. 30 yaitu 150 mg/l tentang Baku mutu untuk kegiatan industri tahu.

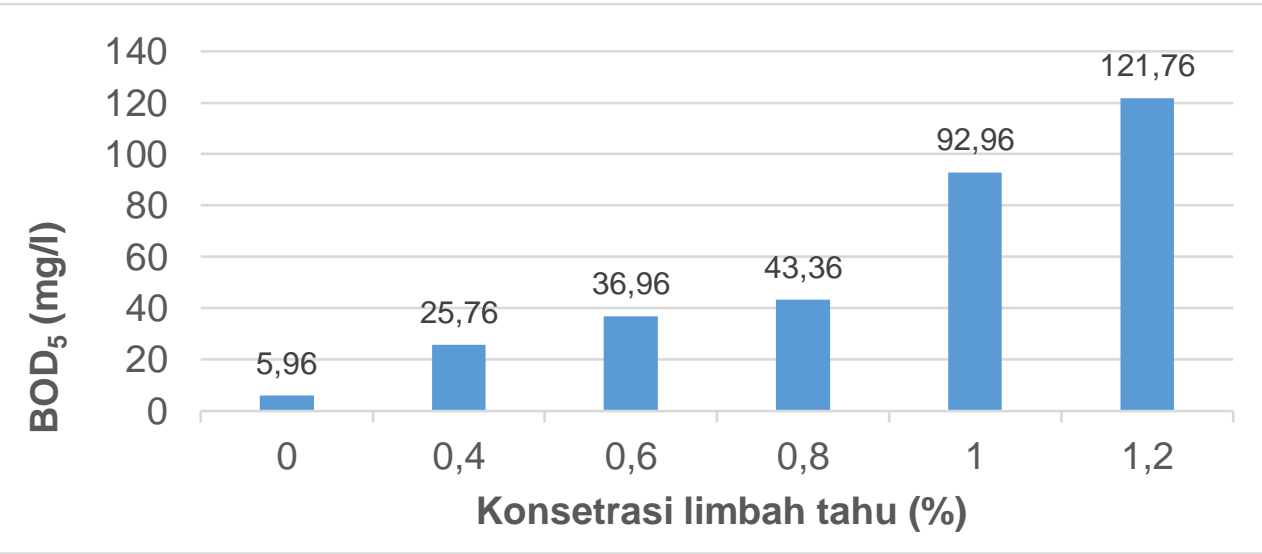

Gambar 5. Hasil pengukuran BOD (mg/l) air dengan konsentrasi limbah tahu yang berbeda 


\section{Chemical Oxygen Demand (COD)}

Kebutuhan oksigen untuk mengoksidasi bahan-bahan organik secara kimiawi biasa disebut COD (Chemical Oxygen Demand). Hasil pengamatan pengukuran COD pada percobaan ada pada Gambar 6. Pada gambar nilai COD perlakuan konsentarsi limbah cair tahu $1,2 \%$ yaitu $785,07 \mathrm{mg} / \mathrm{l}$, termasuk yang tertinggi. Tingginya kandungan COD menunjukkan tingginya bahan organik yang ada dalam limbah dan dapat menyebabkan kondisi anaerobik dan menghasilkan $\mathrm{NH}_{3}, \mathrm{CO}_{2}$ dan $\mathrm{H}_{2} \mathrm{~S}$ (Effendi, 2003). Hasil analisis COD melebihi standar menurut baku mutu Perda Provinisi Kalimantan Timur, mengenai kualitas air dan pengendalian pencemar No. 02 Thn. 2011, Lampiran I. 30 yaitu 300 mg/l, Baku mutu kegiatan industri tahu. Penellitian Dewa \& Idrus (2017), nilai COD pada air limbah tahu melebihi kadar maksimal yang diijinkan, dan apabila tidak dilakukan pengelolaan maka akan mencemari badan perairan. Hasil buangan dari pengolahan tahu dan tempe mengandung kadar COD 7.000-12.000 mg/l (Dahruji et al., 2017).

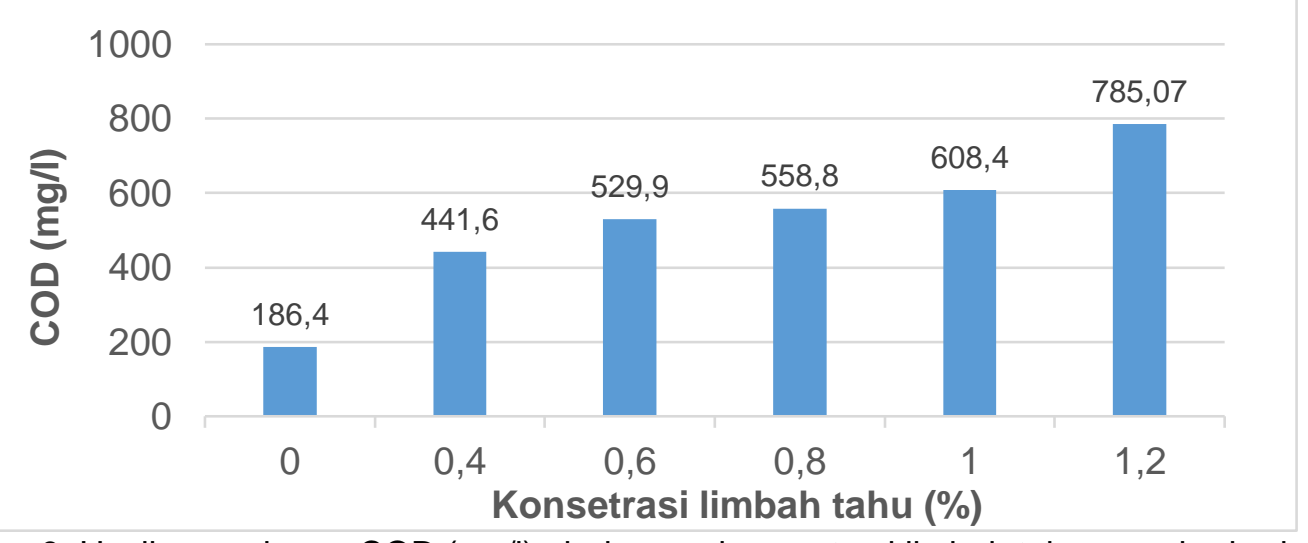

Gambar 6. Hasil pengukuran COD (mg/l) air dengan konsentrasi limbah tahu yang berbeda

\section{Total Suspended Solid}

Bahan padat tersuspensi atau biasa disebut TSS (Total Suspended Solid). Apabila TSS tinggi di perairan, akan menghambat masuknya cahaya yang berpenagruh terhadap proses fotosintesis (Estikarini et al., 2016). Menurut Angraini et al., (2014), peningkatan TDS dan TSS dampaknya terhadap ikan dan zooplankton akan terjadi penyumbatan insang dan berpengaruh terhadap perilaku ikan. Hasil pengukuran TSS pada percobaan yang dilakukan berada pada kisaran 47,5-116 mg/l. Hasil pengukuran dapat dilihat pada Gambar 7. Hasil ini jika dibandingkan dengan baku mutu Perda Provinisi Kalimantan Timur, mengenai kualitas air dan pengendalian pencemar air No. 02 Thn. 2011, Lampiran I. 30 yaitu $100 \mathrm{mg} / \mathrm{l}$, konsentrasi $0,6 \%, 0,8 \%, 1 \%$ dan 1,2\%, melebihi standar yang ditetapkan untuk kegiatan industri tahu. Tingginya kandungan TSS dapat disebabkan dekomposisi bahan organik. Menurut Samsudin et al., (2018), limbah cair tahu dengan kandungan TSS, $B O D$, dan COD yang tinggi, belum memenuhi standar apabila akan dijadikan pupuk organik dalam bentuk cair. 


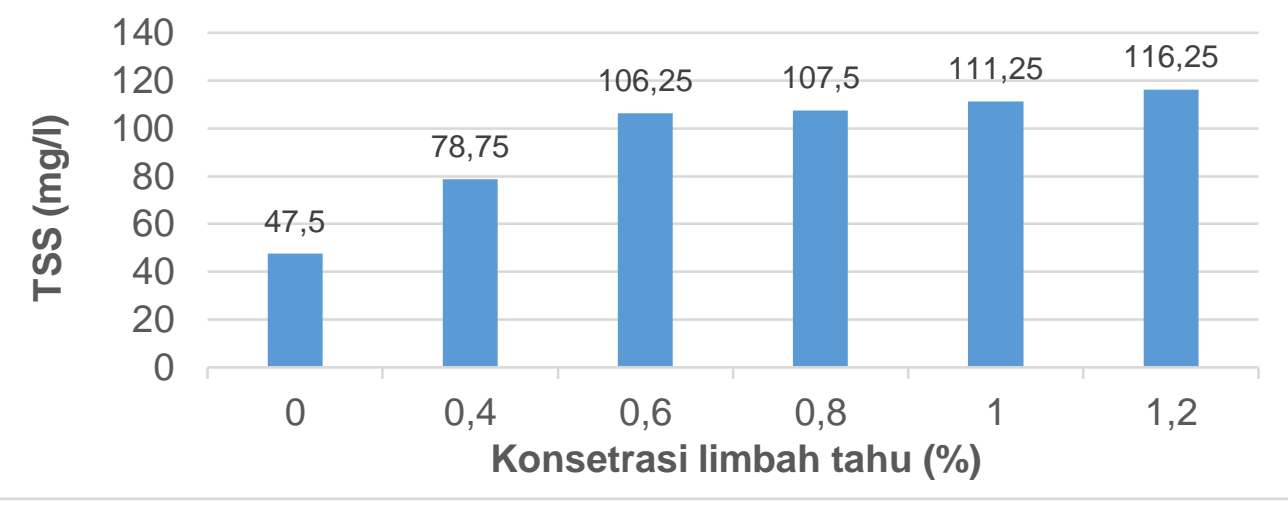

Gambar 7. Hasil pengukuran TSS (mg/l) air dengan konsentrasi limbah tahu yang berbeda

\section{Hidrogen Sulfida $\left(\mathrm{H}_{2} \mathrm{~S}\right)$}

Kandungan hidrogen sulfida yang ada di air limbah karena proses pembusukan dari limbah yang mengandung limbah organik dan belerang (Poppo et al., 2008). Gas dari $\mathrm{H}_{2} \mathrm{~S}$ yang berasal dari hasil dekomposisi bahan organik dapat menyebabkan kerusakan insang, stress bagi ikan yang ada di perairan (Herlambang, 2005). Hasil pengukuran $\mathrm{H}_{2} \mathrm{~S}$ pada Percobaan yang dilakukan yaitu 0,006 - 0,149 mg/l. Penambahan konsentrasi limbah cair tahu $0,4 \%, 0,6 \%, 0,8 \%, 1 \%$ dan $1,2 \%$ mempunyai nilai $\mathrm{H}_{2} \mathrm{~S}$ yang melebihi standar baku mutu $0,05 \mathrm{mg} / \mathrm{l}$. Hasil pengukuran dapat dilihat pada Gambar 8. Tingginya kandungan $\mathrm{H}_{2} \mathrm{~S}$ dapat disebabkan limbah yang mengandung bahan organik mengalami pembusukan.

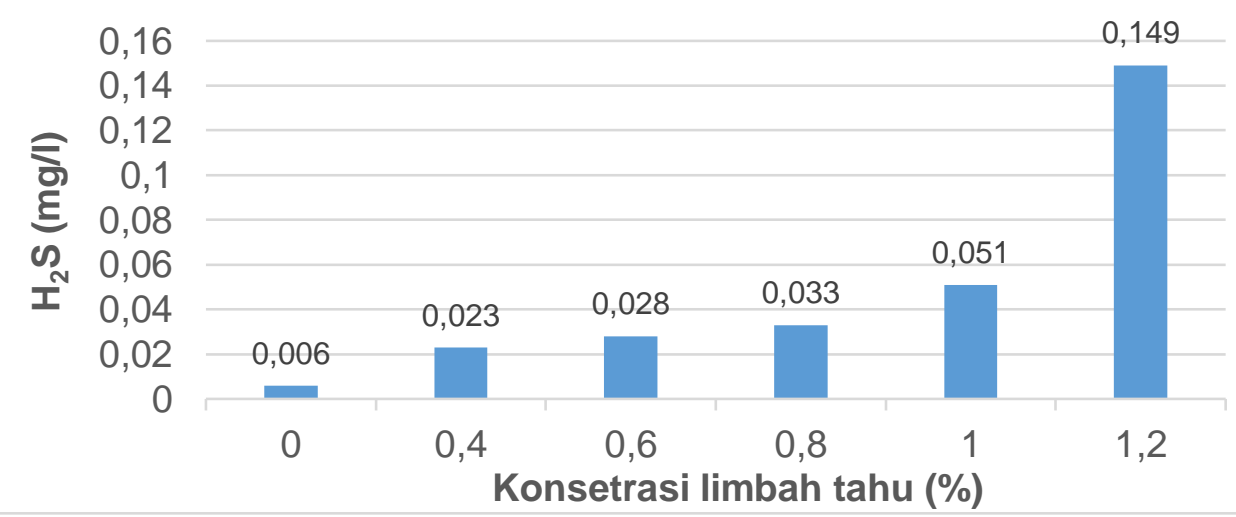

Gambar 8. Hasil pengukuran $\mathrm{H}_{2} \mathrm{~S}(\mathrm{mg} / \mathrm{l})$ air dengan konsentrasi limbah tahu yang berbeda

\section{Amonia $\left(\mathrm{NH}_{3}\right)$}

Amonia $\left(\mathrm{NH}_{3}\right)$ apabila melebihan standar di suatu perairan akan mempengaruhi kehidupan dari biota perairan. Bau menyengat dari amoniak sudah dapat tercium pada konsentrasi amoniak sebesar 0,037 mg/l (Wiryani, 2010). Hasil pengukuran $\mathrm{NH}_{3}$ pada percobaan yang dilakukan berada pada kisaran 0,39-0,94 mg/l. Hasil pengukuran dapat dilihat pada Gambar 9. Hasil ini jika dibandingkan dengan baku mutu masih di bawah standar baku mutu Perda Provinisi Kalimantan Timur, mengenai kualitas air dan pengendalian pencemar air No. 02 Thn. 2011, Lampiran I. 30 yaitu $1 \mathrm{mg} / \mathrm{l}$, baku mutu kegiatan industri tahu. 


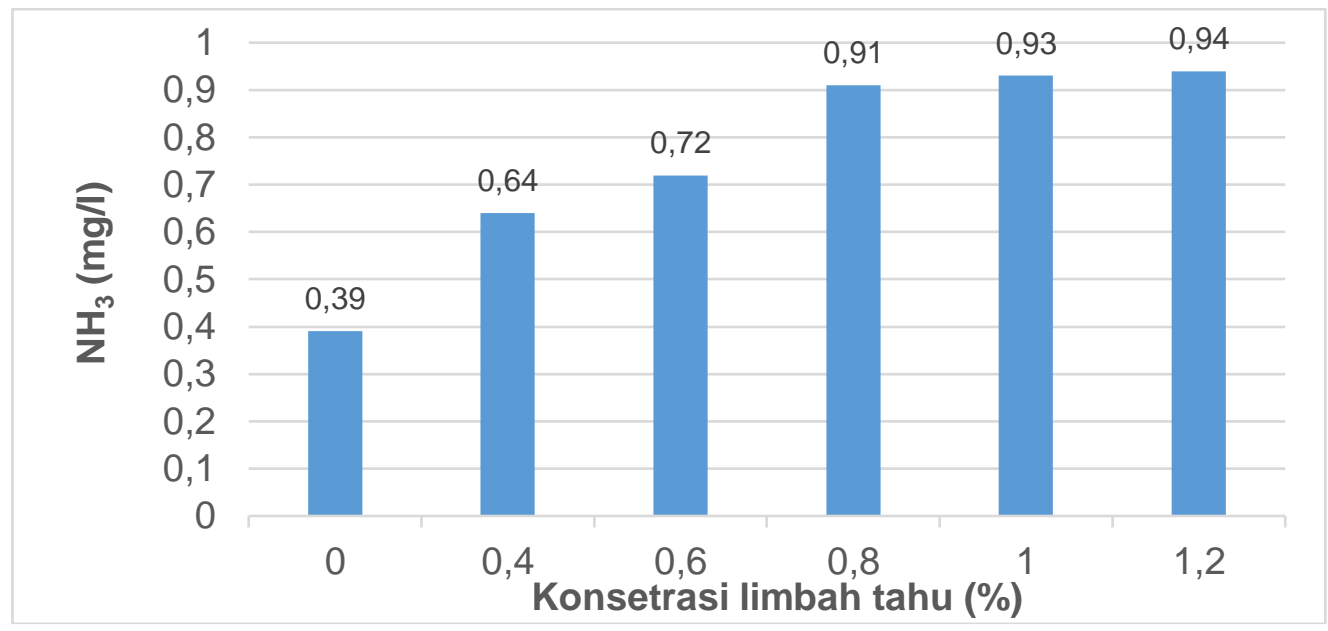

Gambar 9. Hasil pengukuran $\mathrm{NH}_{3}(\mathrm{mg} / \mathrm{l})$ air dengan konsentrasi limbah tahu yang berbeda

\section{Pola Renang dan Tingkah laku Ikan Uji}

Hasil pengamatan pola renang dan tingkah laku ikan uji pada percobaan yang terilhat pada Tabel 2. Pada Tabel terlihat bahwa pada 1 jam setelah limbah diamsukkan kedalam air untuk konsentrasi $0 \%, 0,4 \%, 0,6 \%$ dan $0,8 \%$ masih dalam kondisi normal, sedangkan pada konsentrasi $1 \%$ sebagian ikan berenang dipermukaan, dan pada konsentrasi 1,2\% ikan mulai berenang tidak beraturan. Pada 96 jam, konsentrasi $0 \%$ masih normal, sedangkan pada konsentrasi $0,4 \%, 0,6 \%, 0,8 \%$ dan $1 \%$, ikan ke permukaan dan mulai tidak respon, dan konsentrasi $1,2 \%$, ikan tidak ada yang hidup. Berdasarkan pengamatan tingkah laku ikan mas selama penelitian, ikan pada perlakuan yang diberi limbah cair tahu menunjukan perbedaan perilaku apabila dibandingkan dengan ikan kontrol. Perubahan tingkah laku dapat dilihat mulai awal pemberian limbah cair tahu. Ketika media air mulai diberi air limbah cair tahu, ikan bergerak-gerak menghindari limbah cair tahu. Gejala seperti ini menurut Dewi (2004) merupakan reaksi ikan menghindar dari kualitas air yang memburuk akibat limbah cair tahu. 
Tabel 2. Pengamatan terhadap pola renang dan tingkah laku ikan uji

\begin{tabular}{|c|c|c|c|}
\hline \multirow{2}{*}{ Konsentrasi (\%) } & \multicolumn{3}{|c|}{ Waktu } \\
\hline & 1 jam & 48 Jam & 96 jam \\
\hline 0 & $\begin{array}{l}\text { Pola renang normal dan } \\
\text { respon terhadap } \\
\text { rangsangan }\end{array}$ & $\begin{array}{l}\text { Pola renang normal } \\
\text { dan respon terhadap } \\
\text { rangsangan }\end{array}$ & $\begin{array}{l}\text { Pola renang normal } \\
\text { dan respon terhadap } \\
\text { rangsangan }\end{array}$ \\
\hline 0,4 & $\begin{array}{l}\text { Pola renang normal dan } \\
\text { respon terhadap } \\
\text { rangsangan }\end{array}$ & $\begin{array}{l}\text { Pola renang normal } \\
\text { dan respon terhadap } \\
\text { rangsangan }\end{array}$ & $\begin{array}{l}\text { Pola renang normal, } \\
\text { sesekali berenang di } \\
\text { permukaan dan respon } \\
\text { terhadap rangsangan }\end{array}$ \\
\hline 0,6 & $\begin{array}{l}\text { Pola renang normal dan } \\
\text { respon terhadap } \\
\text { rangsangan }\end{array}$ & $\begin{array}{l}\text { Ikan mulai berenang ke } \\
\text { permukaan dan respon } \\
\text { terhadap rangsangan }\end{array}$ & $\begin{array}{l}\text { Semua ikan berada } \\
\text { dipermukaan dan } \\
\text { sebagian ikan tidak } \\
\text { merespon ketukan }\end{array}$ \\
\hline 0,8 & $\begin{array}{l}\text { Pola renang normal dan } \\
\text { respon terhadap } \\
\text { rangsangan }\end{array}$ & $\begin{array}{l}\text { Seluruh ikan berenang } \\
\text { ke permukaan dan } \\
\text { respon terhadap } \\
\text { rangsangan }\end{array}$ & $\begin{array}{c}\text { Seluruh ikan berenang } \\
\text { normal dan berada di } \\
\text { permukaan }\end{array}$ \\
\hline 1,0 & $\begin{array}{l}\text { Sebagian ikan berenang } \\
\text { di permukaan dan masih } \\
\text { merespon rangsangan }\end{array}$ & $\begin{array}{l}\text { Ikan berenang di sudut } \\
\text { dan bergerombolan } \\
\text { dan masih merespon } \\
\text { terhadap rangsangan }\end{array}$ & $\begin{array}{l}\text { Seluruh ikan berenang } \\
\text { di permukaan dan } \\
\text { masih merespon } \\
\text { terhadap rangsangan }\end{array}$ \\
\hline 1,2 & $\begin{array}{l}\text { Ikan mulai berenang } \\
\text { tidak beraturan dan } \\
\text { masih merespon } \\
\text { rangsangan }\end{array}$ & $\begin{array}{l}\text { Ikan berenang dengan } \\
\text { posisi berdiri, memutar } \\
\text { dan terbalik di } \\
\text { permukaan dan } \\
\text { bergerombolan }\end{array}$ & (2) \\
\hline
\end{tabular}

\section{Kesimpulan}

Hasil pengukuran kualitas air $\mathrm{pH}, \mathrm{DO}, \mathrm{CO}_{2}, \mathrm{COD}$, TSS dan $\mathrm{H}_{2} \mathrm{~S}$ melebihi standar baku mutu, sedangkan suhu, $\mathrm{BOD}_{5}$ dan amoniak masih dibawa standar baku mutu. Konsentrasi limbah cair tahu $0,4 \% ; 0,6 \% ;, 8 \% ; 1,0 \%$ dan 1,2 \% juga berpengaruh terhadap pola renang dan tingkah laku ikan. Limbah industri tahu yang akan dibuang ke perairan, sebaiknya ada proses pengelolaan limbah, untuk meminimalkan dampak negatif terhadap kualitas air dan kelangsungan hidup dari biota perairan.

\section{Daftar Pustaka}

Agung, R., T., \& Winata, H. S. (2011). Pengolahan Air Limbah Industri Tahu Dengan Menggunakan Teknologi Plasma. Jurnal Imiah Teknik Kimia, 2(2), 19-28.

Angraini, Mumu, S., \& Yulianti, P. (2014). Studi Pengolahan Limbah Usaha Mandiri Rumah Tangga dan Dampak Bagi Kesehatan di Wilayah Kenjeran. Reka Lingkungan: Jurnal ITN, 2, 1-10.

Buchori, L., Sasongko, S. B., Anggoro, D. D., \& Aryanti, N. (2012). Pengambilan Minyak Kedelai Dari Ampas Tahu Sebagai Bahan Baku Pembuatan Biodiesel. Jurnal IImu Lingkungan, 10(2), 49. https://doi.org/10.14710/jil.10.2.49-53

Dahruji, Wilianarti, P. F., \& Hendarto, T. (2017). Studi Pengolahan Limbah Usaha Mandiri Rumah Tangga dan Dampak Bagi Kesehatan di Wilayah Kenjeran. Aksiologiya: Jurnal Pengabdian Kepada Masyarakat, 1(1), 36-44. https://doi.org/10.30651/aks.v1i1.304 
Departemen Pertanian. (1983). Pedoman Umum Pengujian Laboratorium Toksisitas Letal Pestisida Pada Ikan. In Departemen Pertanian. Jakarta (Vol. 19). Jakarta.

Dewa, R., \& Idrus, S. (2017). Identifikasi Cemaran Limbah Cair Industri Tahu Di Kota Ambon. Majalah BIAM, 13(2), 11. https://doi.org/10.29360/mb.v13i2.3544

Dewi, N. K. (2004). Penurunan Derajat Toksisitas Kadmium Terhadap Ikan Bandeng (Chanos chanos Forskal) Menggunakan Eceng Gondok (Eichhornia crassipes (Mart.) Solms) dan Fenomena Transportnya. Tesis. Semarang, Universitas Diponegoro.

Effendi, H. (2003). Telaah Kualitas Air. Yogyakarta: Kanisius.

Estikarini, H. D., Hadiwidodo, M., \& Luvita, V. (2016). Penurunan Kadar COD dan TSS Pada Limbah Tekstil Dengan Metode Ozonasi. Jurnal Teknik Lingkungan, 5(1), 1-11.

Hamzani, S., \& Syarifudin, A. (2020). Pengolahan Limbah Cair Industri Tahu Pada Reaktor Anaerobik Sistem Biakan Tersuspensi. Prosiding Seminar Nasional Lingkungan Lahan Basah, 5(3), 52-56.

Herlambang, A. (2005). Penghilangan Bau Secara Biologi Dengan Biofilter Sintetik. Jurnal Air Indonesia, 1(1), 99-112. https://doi.org/10.29122/jai.v1i1.2299

Indah, L. S., Hendrarto, B., \& Soedarsono, P. (2014). Kemampuan Eceng Gondok (Eichhornia sp.), Kangkung Air (Ipomea sp.), dan Kayu Apu (pistia sp.) Dalam Menurunkan Bahan Organik Limbah Industri Tahu (Skala Laboratorium). Management of Aquatic Resources Journal (MAQUARES), 3(1), 1-6. https://doi.org/10.14710/marj.v3i1.4280

Kaswinarni, F. (2008). Kajian Teknis Pengolahan Limbah Padat Dan Cair Industri Tahu. Majalah IImiah Lontar, 22(2), 1-20.

Mardhia, D., \& Abdullah, V. (2018). Studi Analisis Kualitas Air Sungai Brangbiji Sumbawa Besar. Jurnal Biologi Tropis, 18(2), 182-189. https://doi.org/10.29303/jbt.v18i2.860

Matilda, F., Biyatmoko, D., Rizali, A., \& Abdullah, A. (2016). Peningkatan Kualitas Efluen Air Limbah Industri Tahu Pada Sistem Lumpur Aktif Dengan Variasi Laju Alir Menggunakan Arang Aktif Kayu Ulin (Eusideroxylon zwageri). EnviroScienteae, 12(3), 207-215. https://doi.org/10.20527/es.v12i3.2446

Nasir, M., Saputro, E. P., \& Handayani, S. (2015). Manajemen Pengelolaan Limbah Industri. Benefit Jurnal Managemen Dan Bisnis, 19(2), 143-149.

Peraturan Daerah Provinsi Kalimantan Timur. (2011). Peraturan Daerah Provinsi Kalimantan Timut tentang Pengelolaan Kualitas Air dan Pengendalian Pencemar Air Nomor 02 Tahun 2011 tentang Baku mutu Air Limbah Untuk Kegiatan Industri Tahu

Poppo, A., Mahendra, M. S., \& Sundra, I. K. (2008). Studi Kualitas Perairan Pantai di Kawasan Industri Perikanan, Desa Pengabengan, Kecamatan Negara, Kabupaten Jembrana. ECOTROPHIC: Jurnal IImu Lingkungan (Journal of Environmental Science), 3(2).

Rohmani, I. (2014). Uji Toksisitas Akut Limbah Cair Pabrik Tahu Pada Ikan Nila (Oreocromis niloticus) dan Tumbuhan Kayu Apu (Pistia stratiotes). Institut Teknologi Sepuluh Nopember.

Rolia, E., \& Amran, Y. (2015). Perencanaan Bangunan Pengolahan Limbah Cair Pada Pabrik Tahu Di Kelurahan Mulyojati 16 C. Jurnal Tapak, 5(1), 83-88.

Samsudin, W., Selomo, M., \& Natsir, M. F. (2018). Pengolahan Limbah Cair Industri Tahu Menjadi Pupuk Organik Cair Dengan Penambahan Effektive Mikroorganisme-4 (Em4). Jurnal Nasional IImu Kesehatan, 1(2), 1-14. 
ISSN 2354-7251 (print)

Suganda, R., Sutrisno, E., \& Wardana, I. W. (2014). Penurunan Konsentrasi Amonia, Nitrat, Nitrit dan Cod Dalam Air Limbah Tahu Dengan Menggunakan Biofilm - Kolam (Pond) Media Pipa PVC Sarang Tawon dan Tempurung Kelapa Disertai Penambahan Ecotru. Diponegoro University.

Wiryani, E. (2010). Analisis Kandungan Limbah Cair Pabrik Tempe. Jurnal Ekologi Dan Biosistematik, 1, 1-10.

Zulkifili, \& Ami, A. (2001). Pengolahan Limbah Cair Pabrik Tahu Dengan Rotating Biological Contactor (RBC) pada Skala Laboratorium. Limnotek, VIII(1), 21-34. 